\title{
Keanekaragaman, perilaku kunjungan, dan efektivitas serangga penyerbuk pada tanaman mentimun (Cucumis sativus Linn.)
}

\author{
Diversity, foraging behaviour, and effectiveness of \\ insect pollinators on cucumber plants (Cucumis sativus Linn.)
}

\author{
Phika Ainnadya Hasan ${ }^{1}$, Tri Atmowidi ${ }^{{ }^{*}}$, Sih Kahono ${ }^{2}$ \\ ${ }^{1}$ Departemen Biologi, Fakultas Matematika dan Ilmu Pengetahuan Alam, \\ Institut Pertanian Bogor, Kampus Dramaga, Bogor 16680 \\ ${ }^{2}$ Laboratorium Ekologi, Museum Zoologicum Bogoriense, Pusat Penelitian Biologi, LIPI \\ Jalan Raya Jakarta-Bogor KM 46, Cibinong, Bogor 16911
}

(diterima Juli 2015, disetujui Februari 2017)

\begin{abstract}
ABSTRAK
Mentimun merupakan tanaman berumah satu yang dalam proses penyerbukannya memerlukan bantuan penyerbuk. Keanekaragaman dan perilaku kunjungan penyerbuk mempengaruhi efektivitas penyerbukan yang dapat meningkatkan hasil panen. Penelitian ini bertujuan untuk mempelajari keanekaragaman, perilaku kunjungan, dan efektivitas serangga penyerbuk pada tanaman mentimun. Metode scan sampling digunakan untuk pengamatan keanekaragaman penyerbuk, sedangkan pengamatan perilaku kunjungan penyerbuk menggunakan metode focal sampling. Efektivitas penyerbukan diukur dari jumlah buah yang terbentuk pada pertanaman terbuka dan pertanaman dikurung dengan kain kasa. Lima belas spesies serangga ditemukan sebagai penyerbuk pada tanaman mentimun, yaitu Xylocopa confusa Pérez, Xylocopa latipes (Drury), Xylocopa caerulea Fabricius, Ceratina bryanti Cockerell, Amegilla burnensis Lieftinck, Nomia quadridentata Bingham, Nomia sp., Megachile unbripennis Smith, Megachile aff. disjuncta Fabricius, Megachile conjuncta Smith, Campsomeris javana Lepeletier, Syrphus sp., Parasyrphus sp., Eurema hecabe Linnaeus, dan Vanessa cardui Linnaeus. Kunjungan terlama di bunga mentimun ditemukan pada Syrphus sp. (50,71 detik/bunga), sedangkan kunjungan tersingkat ditemukan pada $X$. confusa $(4,78$ detik/bunga). Penyerbukan oleh serangga meningkatkan $100 \%$ jumlah buah normal per tanaman, $77,61 \%$ jumlah biji per buah, dan $28,57 \%$ bobot biji.
\end{abstract}

Kata kunci: aktivitas kunjungan, efek penyerbukan, mentimun, produksibuah, serangga penyerbuk

\begin{abstract}
Cucumber is a monoceous plant and require pollinators for pollination process. Diversity and foraging activity of pollinators affect the effectiveness of pollination, which can improve the yields. The aim of this research were to study the diversity, foraging behavior, and effectiveness of insect pollinators on cucumber plants. Scan sampling was used as on of the methodology for observing pollinator diversity, while foraging behavior was observed using focal sampling. Pollination effectiveness were measured based on the number of fruit set of opened and caged plants. Fifteen species were found as pollinator of cucumber, i.e., Xylocopa confusa Pérez, Xylocopa latipes (Drury), Xylocopa caerulea Fabricius, Ceratina bryanti Cockerell, Amegilla burnensis Lieftinck, Nomia quadridentata Bingham, Nomia sp., Megachile unbripennis Smith, Megachile aff. disjuncta Fabricius, Megachile conjuncta Smith, Campsomeris javana Lepeletier, Syrphus sp., Parasyrphus sp., Eurema hecabe Linnaeus, and Vanessa cardui Linnaeus. The longest visit on cucumber flower
\end{abstract}

\footnotetext{
*Penulis korespondensi: Tri Atmowidi. Departemen Biologi, Fakultas Matematika dan Ilmu Pengetahuan Alam, Institut Pertanian Bogor, Jalan Raya Dramaga, Bogor 16680, Tel: 0251-8622833, Faks: 0251-8622833, Email: atmowidi@gmail.com.
} 
pattern was by Syrphus sp. (50.71 seconds/flower), while the shortest visit was by $X$. confusa (4.78 seconds/flower). Pollination by insects increase $100 \%$ production as measured by healthy fruit per plant. Pollination also increase $77.61 \%$ of seeds number per fruit and $28.57 \%$ of seed weight.

Key words: cucumber, foraging activity, fruit production, insect pollinator, pollination effect

\section{PENDAHULUAN}

Serangga penyerbuk berperan penting dalam penyerbukan berbagai spesies tanaman entomofili, salah satunya adalah mentimun. Mentimun merupakan tanaman berumah satu (bunga jantan dan betina terdapat pada tanaman yang sama), namun dalam proses penyerbukannya membutuhkan bantuan serangga penyerbuk (Delaplane \& Mayer 2000).

Di Indonesia, penelitian tentang serangga penyerbuk tanaman mentimun telah dilaporkan sebelumnya, antara lain lebah Apis cerana Fabricius dan Xylocopa confusa Pérez (Erniwati et al. 2010; Indriani 2014; Pamungkas 2014). Selain itu, beberapa spesies lebah madu juga dilaporkan sebagai penyerbuk tanaman mentimun di berbagai Negara, seperti Apis mellifera Linnaeus di Islamabad (Sarwar et al. 2008), Apis dorsata Fabricius, A. cerana dan Apis florea Fabricius di India (Pateel 2007).

Kajian tentang jumlah spesies dan individu serangga penyerbuk berperan penting dalam penyerbukan tanaman. Kajian perilaku kunjungan serangga pada bunga diperlukan untuk mengetahui potensi dan efektivitasnya dalam penyerbukan tanaman (Atmowidi 2008). Kajian perilaku kunjungan serangga penyerbuk pada tanaman mentimun di Indonesia belum banyak dilaporkan. Rata-rata lama kunjungan $X$. confusa, A. cerana, dan Megachile conjuncta Smith tinggi pada pagi hari dan menurun di sore hari (Erniwati et al. 2010). Serangga-serangga penyerbuk juga dilaporkan meningkatkan jumlah, bobot, dan panjang buah mentimun (Sarwar et al. 2008; Gracy et al. 2008). Dalam penelitian ini dikaji keanekaragaman, perilaku kunjungan, dan efektivitasnya dalam pembentukan buah tanaman mentimun.

\section{BAHAN DAN METODE}

\section{Waktu dan tempat penelitian}

Penelitian ini dilakukan pada bulan AgustusOktober 2014 di lahan pertanian organik Bina
Sarana Bakti, Cisarua, Bogor. Lahan pertanian tersebut berada pada ketinggian 939,5-953,9 $\mathrm{m}$ dpl.

\section{Pengamatan keanekaragaman serangga penyerbuk}

Pengamatan keanekaragaman serangga penyerbuk dilakukan selama 13 hari pada sekitar 350 tanaman mentimun varietas jepang. Pengamatan dilanjutkan pada sekitar 90 tanaman mentimun varietas lokal selama 10 hari karena pertanaman mentimun varietas jepang terserang oleh hama sehingga tidak bisa digunakan untuk pengamatan selanjutnya. Kedua pertanaman terletak pada dua blok pengamatan dengan jarak sekitar 450 meter. Pengamatan dilakukan dengan metode scan sampling (Martin \& Bateson 1986). Pengamatan dilakukan dengan berjalan mengelilingi blok pertanaman selama 15 menit setiap jam dengan interval waktu 5 menit, pada pagi hari (07:00 09:00 WIB), siang hari (10:00-12:00 WIB), dan sore hari (13:00-16:00 WIB). Selama pengamatan dicatat nama spesies dan jumlah individu serangga penyerbuk yang sedang mengunjungi bunga mentimun. Parameter lingkungan, meliputi suhu dan kelembaban udara, intensitas cahaya, dan kecepatan angin diukur setiap hari pengamatan pada pukul 09:00, 11:00, dan 13:00 WIB. Beberapa individu serangga pengunjung bunga dikoleksi menggunakan jaring, kemudian diawetkan secara kering dan/atau basah dalam etanol $70 \%$. Identifikasi spesimen serangga penyerbuk berdasarkan Bolton (1994), Vockeroth \& Thompson (1992), Tsukada (1985), Yata \& Morishita (1991), Holloway (1988), Robinson et al. (1994), Michener (2007), dan Goulet \& Huber (1993). Spesimenjuga diverifikasidengan spesimen koleksi Museum Zoologicum Bogoriense, Lembaga Ilmu Pengetahuan Indonesia, Bogor.

\section{Pengamatan aktivitas kunjungan serangga penyerbuk}

Pengamatan aktivitas kunjungan serangga penyerbuk dilakukan dalam kisaran waktu pukul 07:00-16:00 WIB selama 15 hari di bulan Oktober 2014 pada mentimun varietas jepang dan 
mentimun varietas lokal. Aktivitas kunjungan diamati pada 6 spesies serangga penyerbuk, yaitu $X$. confusa, Megachile spp., M. conjuncta, Ceratina sp., Nomia sp., dan lalat Syrphus sp. Aktivitas kunjungan yang diamati meliputi jumlah bunga yang dikunjungi per menit (foraging rate), lama kunjungan per bunga (handling time), dan total waktu kunjungan per tanaman (Dafni 1992). Pengamatan aktivitas kunjungan menggunakan metode focal sampling (Martin \& Bateson 1986), yaitu mengamati satu individu dari setiap spesies serangga penyerbuk pada setiap kali pengamatan.

\section{Penghitungan pollen load}

Penghitungan pollen load dilakukan pada 2 spesies serangga penyerbuk pertanaman mentimun varietas jepang, yaitu Megachile sp. dan Ceratina sp. Penghitungan pollen load dilakukan pada 10 individu (sebagai ulangan) masing-masing spesies. Satu individu serangga dimasukkan ke dalam microtube yang berisi larutan etanol $70 \%$ dan gliserol dengan perbandingan $4: 1$, kemudian dirotator selama 24 jam. Setelah itu, larutan disentrifugasi selama 5 menit dengan kecepatan $700 \mathrm{rpm}$. Sebanyak 0,02 ml larutan diambil dan diletakkan pada haemositometer tipe Neubauer untuk dihitung jumlah polennya dibawah mikroskop.

\section{Pengukuran efektivitas serangga penyerbuk}

Pengukuran efektivitas serangga penyerbuk dilakukan pada pertanaman mentimun varietas jepang. Lima puluh enam tanaman dikurung dengan kain kasa untuk mencegah berkunjungnya serangga penyerbuk. Lima puluh enam tanaman mentimun lainnya dibiarkan terbuka sehingga serangga dapat berkunjung pada pertanaman. Efektivitas penyerbukan serangga dihitung dari jumlah buah yang terbentuk per tanaman, jumlah buah normal dan tidak normal, bobot buah, panjang buah, diameter buah, bobot biji, dan jumlah biji. Buah normal dicirikan dengan bentuk yang lurus, sedangkan buah tidak normal dicirikan dengan bentuk yang bengkok (Gambar 1).

\section{Analisis data}

Keanekaragaman serangga penyerbuk dihitung dengan indeks keanekaragaman Shannon-Wiener $\left(H^{\prime}\right)$, indeks kemerataan (E), dan indeks kesamaan

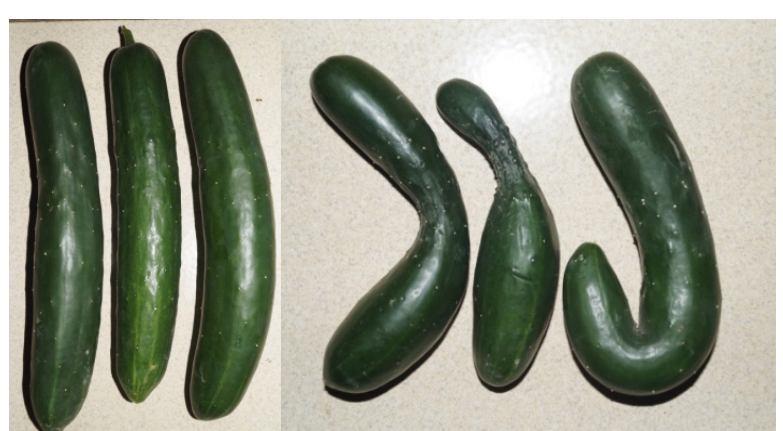

Gambar 1. Buah mentimun. A: normal; dan B: tidak normal.

Sorensen (Cs). Korelasi antara data lingkungan, jumlah individu dan spesies serangga penyerbuk, serta waktu pengamatan dianalisis dengan principal component analysis (PCA) dan korelasi Pearson menggunakan program MINITAB 16. Data kunjungan spesies penyerbuk dianalisis dengan uji Two Independent Samples Test, sedangkan data buah dan biji pertanaman terbuka dan dikurung dianalisis dengan IndependentSamples $t$ Test menggunakan program SPSS 16.0 dengan selang kepercayaan $95 \%$.

\section{HASIL}

\section{Keanekaragaman serangga penyerbuk tanaman mentimun}

Ditemukan 15 spesies serangga penyerbuk tanaman mentimun yang termasuk dalam 3 ordo dan 7 famili. Spesies serangga penyerbuk tersebut ialah Nomia sp., Nomia quadridentata Bingham, Megachile aff. disjuncta Fabricius, Megachile unbripennis Smith, M. conjucta, X. confusa, Xylocopa latipes (Drury), Xylocopa caerulea Fabricius, Ceratina bryanti Cockerell, Amegilla burnensis Lieftinck, dan Campsomeris javana Lepeletier (Hymenoptera), Syrphus sp., Parasyrphus sp. (Diptera), Eurema hecabe Linnaeus, dan Vanessa cardui Linnaeus (Lepidoptera) (Tabel 1 dan 2). Disamping itu, pada bunga mentimun juga dikunjungi oleh serangga yang tidak dikenal sebagai penyerbuk potensial sehingga jumlah individu serangga tersebut tidak dihitung. Spesies tersebut, yaitu Rhynchium haemorrhoidale (Fabricius), Vespa affinis (Linnaeus), Myrmicaria sp. (Hymenoptera), Aulacophora coffeae (Hornstedt), Aulacophora indica (Olivier) (Coleoptera), Leptosia nina 
(Fabricius), Spoladea recurvalis (Fabricius), Nyctemera adversata (Schaller), dan Amata huebneri (Boisduval) (Lepidoptera).

Tingkat kunjungan tertinggi (347 individu varietas lokal dan 450 individu varietas jepang) ke bunga mentimun tercatat pada pagi hari dan terendah (38 individu varietas lokal dan 43 varietas jepang) terjadi pada sore hari (Tabel 1 dan 2). Kesamaan spesies serangga penyerbuk tanaman mentimun antar waktu pengamatan berkisar 70$92 \%$. Kesamaan tertinggi $(92,3 \%)$ terjadi pada pagi vs siang hari pada varietas lokal dan pada siang vs sore $(82,35 \%)$ pada mentimun varietas jepang (Tabel 3).

Parameter lingkungan yang paling mempengaruhi kunjungan serangga penyerbuk pada pagi hari adalah intensitas cahaya (Gambar 2). Hasil analisis korelasi Pearson menunjukkan bahwa hanya intensitas cahaya yang berkorelasi positif secara nyata terhadap jumlah spesies serangga penyerbuk $(\mathrm{r}=0,999, \mathrm{P}=0,033)$, sedangkan parameter lingkungan lainnya, yaitu kelembapan udara dan kecepatan angin tidak berkorelasi nyata dengan jumlah individu dan spesies serangga penyerbuk $(\mathrm{P}>0,05)($ Tabel 4$)$.

\section{Aktivitas kunjungan dan pollen load serangga penyerbuk pada bunga mentimun}

Tiga spesies, yaitu X. confusa, Megachile spp., dan $M$. conjuncta menunjukkan jumlah kunjungan yang tinggi (12,55 bunga/menit, 9,63 bunga/menit, dan 9,61 bunga/menit). Tiga spesies lain yang diamati, yaitu Ceratina sp. (1,79 bunga/menit), Nomia sp. (1,40 bunga/menit), dan Syrphus sp. (1,18 bunga/menit) mengunjungi sedikit bunga per menitnya. Makin banyak jumlah bunga

Tabel 1. Spesies dan jumlah individu serangga penyerbuk pada tanaman mentimun varietas jepang

\begin{tabular}{|c|c|c|c|c|c|}
\hline \multirow{2}{*}{$\begin{array}{l}\text { Ordo } \\
\quad \text { Famili } \\
\quad \text { Spesies }\end{array}$} & \multicolumn{4}{|c|}{ Jumlah individu } & \multirow{2}{*}{$\begin{array}{c}\text { Persentase } \\
(\%)\end{array}$} \\
\hline & Pagi & Siang & Sore & Total & \\
\hline \multicolumn{6}{|l|}{ Hymenoptera } \\
\hline \multicolumn{6}{|l|}{ Halictidae } \\
\hline Nomia sp. & 40 & 14 & 2 & 56 & 8,06 \\
\hline N. quadridentata & 1 & 2 & 1 & 4 & 0,57 \\
\hline \multicolumn{6}{|l|}{ Megachilidae } \\
\hline Megachile spp. & 55 & 42 & 8 & 105 & 15,12 \\
\hline M. conjuncta & 34 & 21 & 3 & 58 & 8,35 \\
\hline \multicolumn{6}{|l|}{ Apidae } \\
\hline Xylocopa confusa & 145 & 55 & 11 & 211 & 30,4 \\
\hline X. caerulea & 4 & 0 & 0 & 4 & 0,57 \\
\hline$X$. latipes & 2 & 0 & 0 & 2 & 0,28 \\
\hline Ceratina sp. & 83 & 38 & 2 & 123 & 17,72 \\
\hline Amegilla sp. & 8 & 0 & 0 & 8 & 1,15 \\
\hline \multicolumn{6}{|l|}{ Scoliidae } \\
\hline Campsomeris javana & 0 & 1 & 0 & 1 & 0,14 \\
\hline \multicolumn{6}{|l|}{ Lepidoptera } \\
\hline \multicolumn{6}{|l|}{ Pieridae } \\
\hline Eurema hecabe & 9 & 7 & 0 & 15 & 2,16 \\
\hline \multicolumn{6}{|l|}{ Nymphalidae } \\
\hline Vanessa cardui & 2 & 1 & 0 & 3 & 0,43 \\
\hline \multicolumn{6}{|l|}{ Diptera } \\
\hline \multicolumn{6}{|l|}{ Syrphidae } \\
\hline Parasyrphus sp. & 6 & 0 & 0 & 6 & 0,86 \\
\hline Syrphus sp. & 62 & 20 & 16 & 98 & 14,12 \\
\hline Jumlah individu & 450 & 201 & 43 & 694 & 100 \\
\hline Jumlah spesies & 13 & 10 & 7 & 14 & \\
\hline Indeks keanekaragaman (H') & 1,92 & 1,86 & 1,58 & 1,92 & \\
\hline Indeks kemerataan $(\mathrm{E})$ & 0,74 & 0,80 & 0,81 & 0,72 & \\
\hline
\end{tabular}


Tabel 2. Spesies dan jumlah individu serangga penyerbuk pada tanaman mentimun varietas lokal

\begin{tabular}{|c|c|c|c|c|c|}
\hline \multirow{2}{*}{$\begin{array}{l}\text { Ordo } \\
\text { Famili } \\
\quad \text { Spesies }\end{array}$} & \multicolumn{4}{|c|}{ Jumlah individu } & \multirow{2}{*}{$\begin{array}{c}\text { Persentase } \\
(\%)\end{array}$} \\
\hline & Pagi & Siang & Sore & Total & \\
\hline \multicolumn{6}{|l|}{ Hymenoptera } \\
\hline \multicolumn{6}{|l|}{ Halictidae } \\
\hline Nomia sp. & 17 & 16 & 3 & 36 & 6,22 \\
\hline N. quadridentata & 2 & 1 & 0 & 3 & 0,51 \\
\hline \multicolumn{6}{|l|}{ Megachilidae } \\
\hline Megachile spp. & 72 & 67 & 11 & 150 & 25,95 \\
\hline M. conjuncta & 6 & 2 & 1 & 9 & 1,55 \\
\hline \multicolumn{6}{|l|}{ Apidae } \\
\hline Xylocopa confusa & 11 & 6 & 3 & 20 & 3,46 \\
\hline X. caerulea & 3 & 2 & 0 & 5 & 0,86 \\
\hline$X$. latipes & 0 & 1 & 0 & 1 & 0,17 \\
\hline Ceratina sp. & 183 & 57 & 13 & 253 & 43,77 \\
\hline Amegilla sp. & 2 & 1 & 0 & 3 & 0,51 \\
\hline \multicolumn{6}{|l|}{ Scoliidae } \\
\hline Campsomeris javana & 0 & 1 & 1 & 2 & 0,34 \\
\hline \multicolumn{6}{|l|}{ Lepidoptera } \\
\hline \multicolumn{6}{|l|}{ Pieridae } \\
\hline Eurema hecabe & 9 & 14 & 3 & 26 & 4,49 \\
\hline \multicolumn{6}{|l|}{ Nymphalidae } \\
\hline Vanessa cardui & 5 & 4 & 0 & 9 & 1,55 \\
\hline \multicolumn{6}{|l|}{ Diptera } \\
\hline \multirow{3}{*}{$\begin{array}{l}\text { Syrphidae } \\
\text { Parasyrphus sp. } \\
\text { Syrphus sp. }\end{array}$} & & & & & \\
\hline & 21 & 2 & 1 & 24 & 4,15 \\
\hline & 16 & 19 & 2 & 37 & 6,4 \\
\hline Jumlah individu & 347 & 193 & 38 & 578 & 100 \\
\hline Jumlah spesies & 12 & 14 & 9 & 14 & \\
\hline Indeks keanekaragaman (H') & 1,55 & 1,79 & 1,76 & 1,70 & \\
\hline Indeks kemerataan (E) & 0,62 & 0,67 & 0,80 & 0,64 & \\
\hline
\end{tabular}

Tabel 3. Kesamaan serangga penyerbuk tanaman mentimun pada pengamatan pagi vs siang, siang vs sore, dan pagi vs sore berdasarkan indeks kesamaan Sorensen

\begin{tabular}{lccc}
\hline & \multicolumn{3}{c}{ Indeks kesamaan Sorensen (\%) } \\
\cline { 2 - 4 } & Pagi vs Siang & Siang vs Sore & Pagi vs Sore \\
\hline Mentimun varietas lokal & 92,3 & 78,26 & 76,19 \\
Mentimun varietas jepang & 78,26 & 82,35 & 70,00 \\
\hline
\end{tabular}

yang dikunjungi per satuan waktu maka waktu kunjungan per bunga makin singkat. Lebah $X$. confusa memerlukan waktu kunjungan per bunga paling singkat (4,78 detik), sedangkan Syrphus sp. memerlukan waktu kunjungan per bunga paling lama (50,71 detik). Waktu yang diperlukan oleh $X$. confusa, Megachile spp., dan M. conjuncta dalam mengunjungi bunga dalam satu tanaman berkisar 13-21 detik, sedangkan pada Ceratina sp., Nomia sp., dan Syrphus berkisar 52-79 detik (Tabel 5). Berdasarkan penghitungan pollen load, lebah
Ceratina sp. membawa sekitar 350 butir polen, sedangkan Megachile sp. membawa sekitar 125 butir polen.

\section{Efektivitas serangga penyerbuk pada tanaman mentimun}

Pada pertanaman mentimun yang terbuka (tidak dikurung kasa) dihasilkan 5,4 buah per tanaman dengan bobot 237,5 g per buah, diameter buah 55,49 mm, dengan 136,46 biji per buah, dan bobot biji 0,018 g per buah. Hasil panen 


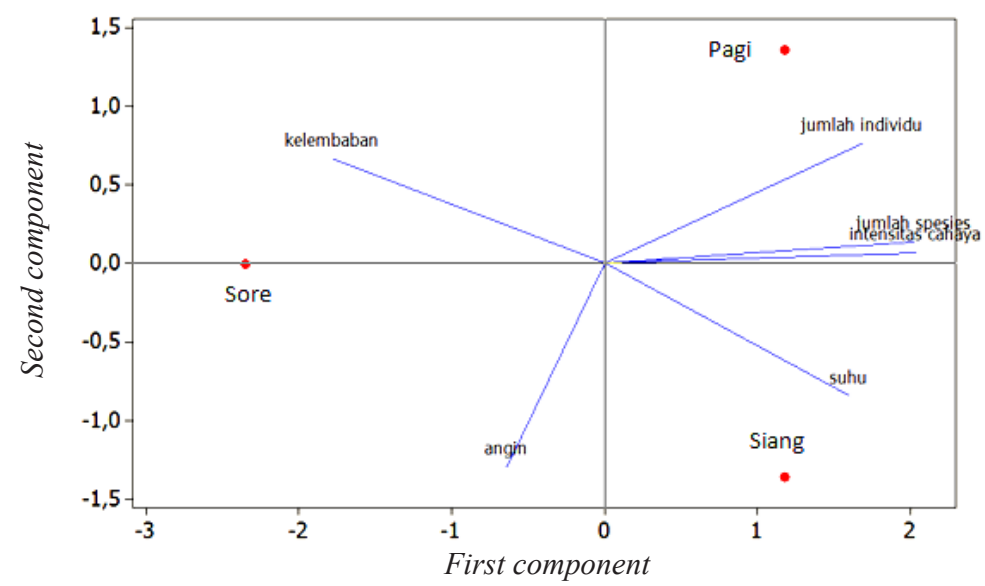

Gambar 2. Hubungan parameter lingkungan, jumlah individu, dan spesies serangga penyerbuk dengan waktu pengamatan berdasarkan analisis principal componen analisis (PCA).

Tabel 4. Hubungan jumlah individu dan spesies serangga penyerbuk dengan parameter lingkungan berdasarkan nilai korelasi Pearson (r: nilai korelasi; P: nilai probabilitas)

\begin{tabular}{lcccc}
\hline & \multicolumn{2}{c}{ Jumlah individu } & \multicolumn{2}{c}{ Jumlah spesies } \\
\cline { 2 - 5 } & $\mathrm{r}$ & $\mathrm{P}$ & $\mathrm{r}$ & $\mathrm{P}$ \\
\hline Suhu udara & 0,303 & 0,804 & 0,719 & 0,489 \\
Kelembapan udara & $-0,447$ & 0,705 & $-0,818$ & 0,390 \\
Intensitas cahaya & 0,854 & 0,348 & 0,999 & 0,033 \\
Kecepatan angin & $-0,792$ & 0,418 & $-0,408$ & 0,732 \\
\hline
\end{tabular}

Tabel 5. Aktivitas kunjungan serangga penyerbuk pada bunga mentimun

\begin{tabular}{lcccc}
\hline \multirow{2}{*}{ Spesies } & $\begin{array}{c}\text { Jumlah } \\
\text { pengamatan } \\
\text { (n) }\end{array}$ & $\begin{array}{c}\text { Total kunjungan per } \\
\text { tanaman (detik) }\end{array}$ & $\begin{array}{c}\text { Lama kunjungan per } \\
\text { bunga (detik) }\end{array}$ & $\begin{array}{c}\text { Jumlah bunga } \\
\text { dikunjungi per menit }\end{array}$ \\
\hline Hymenoptera & & & & \\
$\quad$ Xylocopa confusa & 27 & $17,93 \mathrm{ac}$ & $4,78 \mathrm{a}$ & 12,55 \\
Megachile conjuncta & 15 & $13,73 \mathrm{a}$ & $6,24 \mathrm{~b}$ & 9,61 \\
Megachile spp. & 43 & $21,93 \mathrm{c}$ & $6,23 \mathrm{~b}$ & 9,63 \\
Ceratina sp. & 103 & $52,15 \mathrm{~b}$ & $33,36 \mathrm{c}$ & 1,79 \\
$\quad$ Nomia sp. & 13 & $79,57 \mathrm{~b}$ & $42,81 \mathrm{c}$ & 1,40 \\
Diptera & & & & \\
$\quad$ Syrphus sp. & 9 & $70,70 \mathrm{~b}$ & $50,71 \mathrm{c}$ & 1,18 \\
\hline
\end{tabular}

Huruf yang sama pada kolom yang sama menunjukan nilai tidak berbeda nyata berdasarkan Two Independent Samples Test dengan menggunakan uji Mann-Whitney U.

tersebut lebih tinggi dibandingkan dengan hasil panen tanaman mentimun yang ditutup kain kasa, yaitu 4,8 buah per tanaman, dengan bobot buah $225,83 \mathrm{~g}$, diameter buah $39,57 \mathrm{~mm}$, dengan 76,83 biji per buah, dan 0,014 g bobot biji per buah. Hasil panen pertanaman mentimun yang dibantu penyerbukannya oleh serangga meningkat $100 \%$ jumlah buah normal per tanaman, 77,61\% jumlah biji per buah, dan $28,57 \%$ bobot biji per buah (Tabel 6).

\section{PEMBAHASAN}

Dua varietas mentimun digunakan dalam penelitian ini, yaitu varietas jepang dan varietas lokal sehingga menambah informasi data serangga penyerbuk pada berbagai varietas tanaman mentimun. Secara umum, komposisi spesies serangga penyerbuk pada kedua varietas tersebut adalah sama. Pada mentimun varietas jepang, $X$. confusa ditemukan sebagai penyerbuk dominan, sedangkan pada varietas lokal, Ceratina sp. 
Tabel 6. Jumlah buah yang terbentuk pada pertanaman mentimun yang terbuka dan pertanaman yang dikurung kain kasa

\begin{tabular}{lcccc}
\hline \multirow{2}{*}{ Hasil panen } & $\mathrm{n}$ & \multicolumn{2}{c}{ Pertanaman mentimun } & \multirow{2}{*}{ Peningkatan (\%) } \\
\cline { 3 - 4 } & & Dikurung & Terbuka & \\
\hline Jumlah buah per tanaman & 8 & $4,8 \mathrm{a}$ & $5,4 \mathrm{a}$ & 12,5 \\
Jumlah buah normal per tanaman & 8 & $2,2 \mathrm{a}$ & $4,4 \mathrm{~b}$ & 100 \\
Jumlah buah tidak normal per tanaman & 8 & $2,6 \mathrm{a}$ & $0,75 \mathrm{a}$ & - \\
Bobot buah $(\mathrm{g}) \pm \mathrm{SD}$ & 24 & $225,83 \mathrm{a}$ & $237,5 \mathrm{a}$ & 5,16 \\
Diameter buah $(\mathrm{mm}) \pm \mathrm{SD}$ & 24 & $39,57 \mathrm{a}$ & $55,49 \mathrm{a}$ & 40,23 \\
Panjang buah $(\mathrm{cm}) \pm \mathrm{SD}$ & 24 & $21,84 \mathrm{a}$ & $23,83 \mathrm{a}$ & 8,97 \\
Jumlah biji $\pm \mathrm{SD}$ & 24 & $76,83 \mathrm{a}$ & $136,46 \mathrm{~b}$ & 77,61 \\
Bobot biji $(\mathrm{g}) \pm \mathrm{SD}$ & 30 & $0,014 \mathrm{a}$ & $0,018 \mathrm{~b}$ & 28,57 \\
\hline
\end{tabular}

Huruf yang sama pada baris yang sama menunjukan nilai tidak berbeda nyata dengan uji $\mathrm{T}$ (independent samples $t$ test) dengan selang kepercayaan $95 \%$. $\mathrm{n}=$ jumlah item yang diamati.

ditemukan dominan. Perbedaan spesies dominan yang ditemukan, kemungkinan berkaitan dengan kelimpahan sumber pakan yang berbeda. Apituley et al. (2012) melaporkan bahwa sumber pakan mempengaruhi kelimpahan dan keanekaragaman serangga.

Aktivitas kunjungan serangga penyerbuk yang tinggi terjadi pada pagi hari (sekitar pukul 09:00 WIB) dengan intensitas cahaya yang tidak terlalu tinggi (89,560 lux). Pada sore hari, aktivitas kunjungan serangga penyerbuk makin menurun pada intensitas cahaya yang lebih rendah $(62,800$ lux). Hal ini didukung hasil analisis korelasi Pearson, yang menunjukkan korelasi positif antara jumlah spesies serangga penyerbuk dan intensitas cahaya. Hasil penelitian ini menunjukkan suhu udara tidak berkolerasi dengan jumlah individu dan spesies serangga penyerbuk. Pada tanaman apel, aktivitas terbang serangga penyerbuk dipengaruhi parameter lingkungan, seperti suhu udara, intensitas cahaya, curah hujan, dan kelembapan udara (Joshi \& Joshi 2010).

Penelitian menunjukkan bahwa $X$. confusa mengunjungi bunga dalam waktu yang singkat (rata-rata 4,78 detik/bunga) dan dalam satu menit, lebah ini rata-rata mengunjungi 12,55 bunga dan lama kunjungan pada satu tanaman mencapai 17,93 detik. Demikian juga pada genus Megachile (M. conjuncta dan Megachile spp.) juga mengunjungi banyak bunga (9,61 bunga dan 9,63 bunga) per menitnya dengan lama kunjungan per tanaman mencapai 13,73 detik dan 21,93 detik. Lebah Xylocopa mempunyai ukuran tubuh paling besar dibandingkan dengan serangga penyerbuk lain yang ditemukan dalam penelitian ini. Dengan data kunjungan tersebut, diduga ketiga spesies tersebut merupakan serangga penyerbuk yang efektif pada pertanaman mentimun. Hal yang sama juga dilaporkan oleh Willmer \& Finlayson (2014) bahwa lebah berukuran besar lebih efektif, karena dapat membawa dan mentransfer polen lebih banyak ke kepala putik daripada lebah berukuran kecil. Hasil tersebut juga didukung oleh laporan Thu (2012) bahwa tubuh $X$. confusa dapat membawa 284,67 butir polen. Tiga spesies penyerbuk lainnya, yaitu Ceratina sp., Nomia sp., dan Syrphus sp. diduga bukan sebagai penyerbuk yang efektif pada tanaman mentimun karena mereka tidak banyak berpindah dari satu bunga ke bunga lainnya (rata-rata mengunjungi 1 bunga/ menit) dan kunjungan pada satu bunga relatif lama (Ceratina sp., 33,36 detik, Nomia sp., 42,81 detik, dan Syrphus sp., 50,71 detik).

Peran serangga penyerbuk pada pertanaman mentimun dalam penelitian ini ditunjukkan dengan meningkatnya hasil panen pada pertanaman terbuka yang dibantu penyerbukannya oleh serangga. Pada tanaman dikurung, jumlah dan kualitas buah yang dihasilkan lebih rendah dibandingkan dengan tanaman terbuka. Hal tersebut disebabkan karena pada tanaman yang dikurung tidak adanya serangga yang membantu transfer polen ke kepala putik. Penyerbukan tanaman mentimun yang dikurung kemungkinan terjadi karena penyerbukan oleh angin sehingga hanya sedikit bakal biji yang dapat dibuahi. Sedikitnya jumlah bakal biji yang dibuahi dapat mempengaruhi kualitas dan ukuran buah. Hasil penelitian ini menunjukkan bahwa buah dengan jumlah biji yang banyak (136 biji) memiliki bobot 
buah yang lebih berat (237 g). Hopping (1976) melaporkan jumlah biji berkorelasi positif dengan bobot buah. Proses pembuahan pada tanaman akan diikuti dengan pembelahan yang dipengaruhi zat pengatur tumbuh, seperti auksin, giberelin, sitokinin, dan faktor pertumbuhan lainnya yang akan memacu perkembangan buah (Hopping 1976).

\section{KESIMPULAN}

Lima belas spesies serangga penyerbuk ditemukan pada pertanaman mentimun, yaitu $X$. confusa, X. latipes, X. caerulea, C. bryanti, A. burnensis, N. quadridentata, Nomia sp., M. unbripennis, $M$. aff. disjuncta, $M$. conjuncta, $C$. javana, Syrphus sp., Parasyrphus sp., E. hecabe, dan $V$. cardui. Lebah yang ditemukan dominan adalah $X$. confusa dan Ceratina sp. Lebah $X$. confusa dan Megachile spp. mengunjungi 9-12 bunga/menit dan hanya memerlukan sekitar 4-6 detik/bunga. Lebah $X$. confusa dan Megachile spp. diduga merupakan spesies yang efektif dalam penyerbukan tanaman mentimun. Penyerbukan dengan bantuan serangga pada tanaman mentimun meningkatkan $100 \%$ jumlah buah normal per tanaman, $77,61 \%$ jumlah biji per buah, dan $28,57 \%$ bobot biji per buah.

\section{DAFTAR PUSTAKA}

Apituley FL, Leksono AS, Yanuwiadi B. 2012. Kajian komposisi serangga polinator tanaman apel (Malus sylvestris Mill) di desa Poncokusumo kabupaten Malang. El-Hayah 2:85-96.

Atmowidi T. 2008. Keanekaragaman dan Perilaku Kunjungan Serangga Penyerbuk serta Pengaruhnya terhadap Pembentukan Biji Tanaman Caisin (Brassicarapa L.: Brassicaceae). Disertasi. Bogor: Institut Pertanian Bogor.

Bolton B. 1994. Identification Guide to the Ant Genera of the World. London: Harvard University Press.

Dafni A. 1992. Pollination Ecology: a Practical Approach. Oxford: Oxford University Press.

Delaplane KS, Mayer DF. 2000. Crop Pollination by Bees. New York: CABI Publishing. doi: https:// doi.org/10.1079/9780851994482.0000.

Erniwati, Kahono S, Uji T. 2010. Kajian Ekologi Lebah Sosial (Hymenoptera: Apidae) dan Biologi
Reproduksi Tanaman Pertanianyang Mendukung Konsep Pengembangan Pengelolaan. Laporan Akhir Program Insentif Peneliti dan Perekayasa LIPI. Bogor: Pusat Pengembangan Biologi LIPI. Goulet H, Huber JT. 1993. Hymenoptera of the World: an Identification Guide to Families. Canada: Canada Communication Group-Publishing.

Gracy RG, Rai AB, Kumar A, Chaurasia SNS, Rai M. 2008. Effect of Apis mellifera pollination on the yield attributing characters and yield of cucumber (Cucumis sativus L.). Vegetable Science 35:201-202.

Holloway JD. 1988. The Moths of Borneo: Family Arctiidae, Subfamilies Syntominae, Euchromiinae, Arctiinae; Noctuidae misplaced in Arctiidae (Camptoloma, Aganainae). Kuala Lumpur: Southdene.

Hopping ME. 1976. Effect of exogenous auxins, gibberellins, and cytokinins on fruit development in chinese gooseberry (Actinidia chinensis Planch.). New Zealand Journal of Botany. 14:69-75. doi: https://doi.org/10.1080/002882 5X.1976.10428652.

Indriani C. 2014. Keanekaragaman Serangga Penyerbuk pada Pertanaman Mentimun: Pengaruh Keberadaan Habitat Alami. Skripsi. Bogor: Institut Pertanian Bogor.

Joshi NC, Joshi PC. 2010. Foraging behaviour of Apis spp. on apple flowers in a subtropical environment. New York Science Journal 3:71-76.

Martin P, Bateson P. 1986. Measuring Behavior: an Introductory Guide. Cambridge: Cambridge University Press.

Michener CD. 2007. The Bees of the World. $2^{\text {nd }}$ ed. Baltimore: The Johns Hopkins University Press.

Pamungkas BA. 2014. Pengaruh Kondisi Lahan Pertanian Terhadap Kelimpahan Serangga Penyerbuk Implikasi Terhadap Produksi Mentimun. Skripsi. Bogor: Institut Pertanian Bogor.

Pateel MC. 2007. Impact of Honeybee Pollination on Qualitative and Quantitative Parameters of Cucumber (Cucumis sativa L.). Thesis. Dharwad: University of Agricultural Science.

Robinson GS, Tuck KR, Shaffer M. 1994. A Field Guide to The Smaller Moths of South-East Asia. Kuala Lumpur: Malaysian Nature Society.

Sarwar G, Aslam M, Munawar MS, Raja S, Mahmood R. 2008. Effect of honey bee (Apis mellifera L.) pollination on fruit setting and yield of cucumber (Cucumis sativus L.). Pakistan Entomologist 30:185-191.

Thu MK. 2012. Pollination biology of Cucumis sativus L. (Cucumber) in Hmawbi Township. Universities Research Journal 5:189-199. 
Tsukada E. 1985. Butterflies of the South East Asian Island IV Nymphalidae (I). Tokyo: PLAPAC Co Ltd.

Vockeroth JR, Thompson FC. 1992. Syrphidae. In: McAlpine JF, Rudnitski SM (editor). Manual of Nearctic Diptera. Vol. 2. pp. 718-720. Ottawa: Canada Communication Group-Publishing.
Willmer PG, Finlayson K. 2014. Big bees do a better job: intraspecific size variation influences pollination effectiveness. Journal of Pollination Ecology 14:244-254.

Yata O, Morishita K. 1981. Butterflies of the South East Asian Island II Pieridae-Danaidae. Tokyo: PLAPAC Co.Ltd. 